\title{
PENGARUH PROMOSI PENJUALAN TERHADAP KEPUTUSAN PEMBELIAN MEBEL PADA CV. LAUTAN REZEKI PEKANBARU
}

\author{
Rizqi Fakhri \\ Sekolah Tinggi Ilmu Ekonomi Riau \\ E-mail: rizqifakhri@lecturer.stieriau-akbar.ac.id
}

\begin{abstract}
This study aims to Know Sales Promotion Effect on Purchase Decision Furniture at CV. Lautan Rezeki Pekanbaru. The sample in this study amounted to 51 store, while the sampling technique using Accidental Sampling method. The data analysis in this study with descriptive and quantitative methods with simple linear regression. Based on the research results through tests $T$, the value is greater thitung 7,002 dati t table with ttable value of 2,009, with a significance level of $0.000<0.05$. Thus, it means sales promotion variable $(X)$ significantly influence the purchase decision variable $(Y)$. It can be concluded that promotional sales significantly influence buying decisions Furniture on the $C V$. Lautan Rezeki Pekanbaru. Based on the result of determination, so in this study can be concluded that the sales promotion variable effect of $50 \%$ on purchasing decisions furniture in the CV. Lautan Rezeki Pekanbaru. while the remaining $50 \%$ is influenced by other variables that are ignored or are not examined in this study.
\end{abstract}

Keywords: Sales Promotion, Purchase Decision

\section{A. PENDAHULUAN}

Perkembangan dan kemajuan industry, salah satunya dapat kita lihat dengan adanya perkembangan dunia usaha yang semakin pesat. Banyaknya perusahaan yang bermunculan sehingga menambah persaingan pasar yang membuat persaingan semakin ketat. Sebagai sebuah perusahaan harus mampu mengikuti persaingan pasar tersebut agar eksistensi perusahaan tetap berjalan dengan baik bahkan semakin maju, apalagi tuntutan konsumen semakin meningat juga.

Persaingan yang semakin luas menyebabkan harus adanya strategi pemasaran yang dapat membuat usahanya tetap berkembang. Supaya berhasil, perusahaan harus melakukan tugasnya melebihi pesaing dalam memuaskan konsumen sasaran. Maka, strategi pemasaran harus disesuaikan menurut kebutuhan konsumen maupun kebutuhan strategi pesaing. Merancang strategi pemasaran yang kompetitif dimulai dengan melakukan analisis terhadap pesaing.

Promosi sebagai salah satu unsur bauran pemasaran pemasaran mempunyai peranan yang sangat penting dalam menjalankan kegiatan perusahaan. Salah satu peranannya adalah meningkatkan volume penjualan barang dan jasa untuk memperkenalkan produknya. Suatu barang dan jasa tidak akan dikonsumsi oleh masyarakat, bila masyarakat tidak mengetahui faedah atau nilai yang diberikan oleh suatu barang dan jasa kepada mereka.

Dalam perkembangan selanjutnya, maka konsumen menjadi faktor kunci penentu atas keberhasilan atau kegagalan suatu perusahaan di dalam memasarkan produknya. Perusahaan harus mampu mengenali secara dini apa yang menjadi kebutuhan dan harapan konsumen saat ini maupun masa yang akan datang. Disinilah dibutuhkan seorang manajer pemasaran yang mempunyai pengetahuan seksama tentang perilaku konsumen agar dapat memberikan definisi pasar yang baik untuk mengikuti perubahan yang terus-menerus ini, serta untuk merancang bauran pemasaran yang tepat.

Meningkatkan tingkat keuntungan atau laba operasional perusahaan. Hal ini dapat dilakukan, jika perusahaan dapat mempertahankan dan meningkatkan penjualan produk atau jasa yang mereka produksi. Dengan melakukan penerapan strategi pemasaran yang akurat melalui pemanfaatan peluang dalam meningkatkan penjualan, sehingga posisi atau kedudukan perusahaan dipasar dapat ditingkatkan atau dipertahankan. Sehubungan dengan hal tersebut pelaksanaan pemasaran modern dewasa ini mempunyai peranan yang sangat besar sebagai penunjang langsung terhadap peningkatan laba perusahaan. Promosi sebagai salah satu unsur bauran pemasaran 
mempunyai peranan yang sangat penting dalam menjalankan kegiatan perusahaan. Salah satu peranannya adalah meningkatkan volume penjualan barang dan jasa perusahaan.

Selain itu juga promosi juga merupakan salah satu usaha perusahaan untuk memperkenalkan produknya. Suatu barang dan jasa tidak akan dikonsumsi oleh masyarakat, bila masyarakat tidak mengetahui faedah atau nilai yang diberikan oleh suatu barang atau jasa kepada mereka, informasi dimana produk itu dibeli, berapa harga dari produk itu, kegunaan atau manfaat yang ditimbulkan dari produk itu, cara penggunaannya dan lain-lain. Oleh sebab itu perusahaan harus dapat meberikan informasi tersebut kepada konsumen atau masyarakat secara jelas melalui media yang efektif. Promosi mampu merangsang permintaan akan suatu produk. Dengan promosi tersebut diharapkan konsumen yang sudah ada agar membeli produk lebih sering lagi sehingga akan terjadi pembelian ulang dan volume penjualan produk suatu perusahaan akan meningkat.

Setiap konsumen akan melakukan keputusan pembelian, konsumen melakukan evaluasi mengenai sikapnya. Kepercayaan digunakan konsumen untuk mengevaluasi sebuah merk, kemudian dia akan dapat mengambil keputusan membeli atau tidak, untuk seterusnya konsumen akan loyal atau tidak. Hal ini berlaku juga pada CV. Lautan Rezeki Pekanbaru yang merupakan perusahaan yang memproduksi dan menjual berbagai jenis mebel.

Sebagai perusahaan untuk mencari laba dan menarik minat dari konsumen, $\mathrm{CV}$. Lautan Rezeki juga tidak terlepas dari perencanaan bagaimana untuk meningkatkan laba perusahaan. Berikut media promosi yang digunakan oleh perusahaan dalam mempromosikan produk mebel di perusahaan CV. Lautan Rezeki Pekanbaru

Eko dan Bisnis (Riau Economics and Business Reviewe) Volume 11, Nomor 3, 27 September 2020
Tabel 1

Media Promosi Mebel Pada CV. Lautan Rezeki Mebel Pekanbaru

\begin{tabular}{|c|c|c|}
\hline Tahun & Bauran Promosi & Media Promosi \\
\hline \multirow{4}{*}{2015} & \multirow{4}{*}{ Promosi penjualan } & Produk Sampel \\
\hline & & Undian \\
\hline & & Demonstrasi \\
\hline & & Diskon \\
\hline \multirow{4}{*}{2016} & \multirow{4}{*}{ Promosi penjualan } & Produk Sampel \\
\hline & & Undian \\
\hline & & Demonstrasi \\
\hline & & Diskon \\
\hline \multirow{4}{*}{2017} & \multirow{4}{*}{ Promosi penjualan } & Produk Sampel \\
\hline & & Undian \\
\hline & & Demonstrasi \\
\hline & & Diskon \\
\hline \multirow{4}{*}{2018} & \multirow{4}{*}{ Promosi penjualan } & Produk Sampel \\
\hline & & Undian \\
\hline & & Demonstrasi \\
\hline & & Diskon \\
\hline \multirow{4}{*}{2019} & \multirow{4}{*}{ Promosi penjualan } & Produk Sampel \\
\hline & & Undian \\
\hline & & Demonstrasi \\
\hline & & Diskon \\
\hline
\end{tabular}

Sumber: CV. Lautan Rezeki Pekanbaru, 2020

Dari tabel diatas dilihat bahwa media promosi yang diganakan perusahaan cat tembok jotun CV. Lautan Rezeki Pekanbaru yang terdiri dari Produk sampel, undian, demonstrasi, diskon.

Perusahaan perlu untuk memiliki strategi agar dapat mencapai visi dan misi yang telah dirancang oleh perusahaan. Strategi dirasa penting karena dalam strategi inilah maka perusahaan dapat memutuskan dan mengambil keputusan yang paling tepat untuk menghadapi persaingan yang abadi dalam pasar. Strategi yang diterapkan oleh CV. Lautan Rezeki Pekanbaru saat ini promosi dari mulut ke mulut konsumen yang satu ke konsumen yang lainnya. Kemudian memberikan diskon khusus terhadap produk tertentu. Agar CV. Lautan Rezeki Pekanbaru dapat bertahan dan berkembang dengan baik maka CV. Lautan Rezeki Pekanbaru harus dapat menciptakan kemampan bersaing baik dalam hal jenis produk, maupun promosi sehingga dapat menghasilkan produk yang mampu bersaing dan memenangkan persaingan.

Dengan melihat kondisi tersebut, maka dapat diidentifiksai adanya permasalahan dalam penjualan mebel pada CV. Lautan Rezeki Pekanbaru. Untuk mengatasi permasalahan penurunan dan perubahan penjualan maka perusahaan menggunakan strategi pemasaran seperti personal selling, dan sales promotion. Hal ini dilakukan untuk membuat konsumen

P.ISSN: $1410-7988$

E.ISSN: 2614-123X 
memutuskan membeli mebel pada CV. Lautan Rezeki Pekanbaru.

\section{TINJAUAN PUSTAKA \\ Promosi}

Promosi menurut Graffin dan Ebert (2008 : 352) mengemukakan definisi sebagai berikut : Promosi merupakan teknik apapun yang dirancang untuk menjual suatu produk".

Dapat disimpulkan bahwa promosi merupakan kegiatan perusahaan untuk memberikan informasi, membujuk dan mengingatkan pihak lain melakukan tindakan pembelian terhadap produk perusahaan. Agar kegiatan promosi yang dilakukan dapat berhasil dengan baik, maka promosi tersebut harus direncanakan terlebih dahulu.

\section{Promosi Penjualan}

Menurut Kolter dan Armstrong (2008 : 204) promosi penjualan adalah insentif jangka pendek untuk mendorong penjualan produk atau jasa. Menurut Fandy Tjiptono (2008:546), promosi penjualan merupakan segala bentuk penawaran atau insentif jangka panjang yang ditujukan bagi pembeli, pengecer atau pedagang grosir dan dirancang untuk memperoleh respon spesifik dan segera.

Sedangkan menurut pendapat Philip Kotler dan Gary Armstrong (2004:660), menyatakan bahwa:

"Promosi penjualan adalah insentif-insentif jangka pendek untuk mendorong pembelian atau penjualan produk atau jasa".

\section{Indikator Promosi Penjualan}

Selain Memperharikan alat-alat promosi penjualan perusahaan harus bisa memilih indicator-indikator promosi penjualan yang tepat dalam mempromosikan produk. Menurut Kotler-Keller dalam kurniawan (2020:23) diantaranya:

1. Frekuensi Promosi. Adalah jumlah promosi penjualan yang dilakukan dalam suatu waktu melalui media promosi penjulan

Eko dan Bisnis (Riau Economics and Business Reviewe) Volume 11, Nomor 3, 27 September 2020
2. Kualitas Promosi. Adalah tolak ukur seberapa baik promosi penjulan dilakukan.

3. Kuantitas Promosi. Adalah nilai atau jumlah promosi penjualan dilakukan perusahaan

4. Waktu Promosi. Adalah lamanya promosi yang dilakukan oleh perusahaan

5. Ketepatan atau kesesuaian sasaran promosi merupakan factor yang diperlukan untuk mencapai target yang diiginkan perusahaan.

\section{Pengertian Keputusan Pembelian}

Danang Sunyoto (2013 : 82), keputusan konsumen dalam membeli terdiri atas proses merasakan dan mengevaluasi informasi merek produk, mempertimbangkan bagaimana alternative mereka apa yang akan dibeli.

Selanjutnya menurut Buchari Alma (2011:97), keputusan pembelian adalah proses merumuskan berbagai alternative guna menjauhkan pilihan pada salah satu alternative tertentu untuk melakukan pembelian.

\section{Indikator Keputusan Pembelian}

Menurut Swastha dan Irawan (2008:118) keputusan pembelian adalah keputusan yang diambil oleh pembeli sebenarnya merupakan kumpulan dari jumlah keputusan. Indicator pengukuran variabel keputusan pembelian adalah sebagai berikut:

1. Menganalisa keinginan dan kebutuhan

2. Menilai beberapa sumber yang ada

3. Mengindentifikasi alternative yang ada

4. Mengambil keputusan untuk membeli

5. Perilaku sesudah pembeli

\section{Pengaruh Promosi Penjualan Terhadap Keputusan Pembelian}

Menurut Kotler yang dikutip oleh Benyamin Molen (2007 : 299), perusahaanperusahaan yang menggunakan alat promosi penjualan untuk memperoleh tanggapan pembeli yang lebih kuat dan lebih cepat. Untuk memahaminya para

$$
\text { P.ISSN: 1410-7988 E.ISSN: 2614-123X }
$$


pemasar harus mengetahui kegunaan, persepsi, preferensi, dan perilaku belanja pelanggan sasaran mereka. Seluruh alat-alat promosi penjualan sangat berpengaruh terhadap keputusan pembelian konsumen. Promosi penjualan merupakan suatu rangsangan yang dapat menarik perhatian konsumen untuk melakukan pembelian lebih banyak.

\section{METODE}

\section{Lokasi Penelitian}

Penelitian ini dilaksanakan di CV. Lautan Rezeki Pekanbaru yang beralamat di Jl. Arengka II, komplek Pergudangan Avian Blok A no 27 Pekanbaru.

\section{Jenis dan Sumber Data Data primer}

Data primer adalah data asli yang dikumpulkan sendiri oleh peneliti untuk menjawab masalah penelitiannya secara khusus. Dalam penelitian ini data primer diperoleh secara langsung dengan menyebarkan kuesioner kepada konsumen CV. Lautan Rezeki Pekanbaru.

\section{Data sekunder}

Data skunder adalah data yang bersumber dari catatan yang ada pada tempat penelitian dan dari sumber lainnya yaitu dengan mengadalakan studi kepustakaan mengenai objek penelitian serta sumbersumber lain yang relevan.Dalam penelitian ini data sekunder berupa data, arsip atau dokumen CV. Lautan Rezeki Pekabaru yang berhubungan dengan penelitian ini.

\section{Populasi}

Populasi merupakan sekelompok benda, kejadian, atau orang yang dijadikan objek penelitian, atau populasi adalah keseluruhan kelompok orang, kejadian atau minat yang ingin diteliti oleh peneliti ( Sekaran,2003), dalam metodologi penelitian riset bisnis Roni Andespa. Dalam penelitian ini yang menjadi populasinya adalah seluruh konsumen yang melakukan pembelian mebel pada tahun 2016 pada CV. Lautan Rezeki Pekanbaru yaitu 103 konsumen.

\section{Sampel}

Eko dan Bisnis (Riau Economics and Business Reviewe) Volume 11, Nomor 3, 27 September 2020
Menurut Danang Sunyoto (2013: 13), sampel adalah bagian dari populasi yang ingin diteliti, dipandang sebagai suatu pandangan terhadap populasi, bukan populasi itu sendiri. Semua populasi dijadikan sampel.

Untuk menentukan sampel yang akan digunakan dalam penelitian yang menggunakan metode Sampling Accidental. Teknik sampling accidental dilakukan apabila pemilihan anggota sampelnya dilakukan terhadap orang atau benda yang kebetulan ada atau dijumpai dan dipandang orang yang dijumpai tersebut cocok dijadikan sumber data.

Cara atau pedoman didalam menentukan sampel menurut pendapat Slovin dalam buku metodologi riset bisnis Roni Andespa: $\mathrm{n}=\frac{N}{1+N e^{2}}$

Keterangan :

$\mathrm{n}=$ Besar sampel dalam penelitian

$\mathrm{N}=$ Besar populasi dalam penelitian

$\mathrm{e}=$ error atau tingkat kesalahan dalam pengambilan sampel $(10 \%)$

$$
\begin{aligned}
& \mathrm{n}=\frac{N}{1+N e^{2}} \\
& \mathrm{n}=\frac{103}{1+103 \times 0,01} \\
& \mathrm{n}=\frac{103}{1+1.03} \\
& \mathrm{n}=\frac{103}{2.03} \\
& \mathrm{n}=50.73 \\
& \mathrm{n}=51 \text { (dibulatkan) }
\end{aligned}
$$

Konsumen yang melakukan keputusan pembelian produk - produk mebel pada $\mathrm{CV}$. Lautan Rezeki Pekanbaru, Berdasarkan rumus Slovin di atas maka sampel yang akan digunakan dalam penelitian ini adalah 50,73 outlet yang kemudian dibulatkan menjadi 51 outlet atau konsumen yang menjadi sampel dalam penelitian ini.

\section{Analisis Data}

Penelitian ini menggunakan analisis deskriptif dan kuantitatif. Menurut Suharsimi Arikunto (2010: 282), deskriptif adalah membandingkan antara kenyataan yang sebenarnya dengan teori-teori yang ada hubungannya dengan permasalahan 
guna menarik suatu kesimpulan dan ditabulasikan dalam bentuk tabel-tabel distribusi frekuensi. Menurut Sugiyono (2009: 8), kuantitatif adalah penelitian berdasarkan pada data yang dapat dihitung untuk menghasilkan penaksiran yang kokoh

\section{HASIL}

\section{Metode Deskriptif}

Berdasarkan hasil uji deskriptif diperoleh hasil bahwa seluruh variabel dalam penelitian dikatakan baik dengan rata-rata 4.03 untuk variabel promosi penjualan. Sedangan untuk variabel keputusan membeli juga dinilai baik dengan rata-rata 3.86. Maka dapat disimpulakn bahwa promosi penjualan yang dilakukan oleh dapat dikatakan baik.

\section{Metode Kuantitatif}

\section{Uji Regeresi Linier Sederhana}

Analisis yang digunakan umtuk melihat arah hubungan antara variabel bebas terhadap terikat, serta untuk melihat besaran perubahan peningkatan variabel terikat, akibat dari perubahan variabel bebas sebesar satu-satuan. Berikut adalah hasil output regresi linier sederhana

Tabel 2 Regresi Linier Sederhana

\begin{tabular}{|c|c|c|c|c|c|c|}
\hline \multicolumn{7}{|c|}{ Coefficients $\mathrm{a}^{\mathrm{a}}$} \\
\hline \multirow{2}{*}{\multicolumn{2}{|c|}{ Model }} & \multicolumn{2}{|c|}{ Unstandardized Coefficients } & $\begin{array}{c}\text { Standardized } \\
\text { Coefficients }\end{array}$ & \multirow[b]{2}{*}{$t$} & \multirow[b]{2}{*}{ Sig. } \\
\hline & & $B$ & Std. Error & Beta & & \\
\hline \multirow[t]{2}{*}{1} & (Constant) & 12.266 & 3.802 & & 3.226 & .002 \\
\hline & Promosi_Penjualan & .655 & .093 & .707 & 7.005 & .000 \\
\hline
\end{tabular}

a. Dependent Variable: Keputusan_Pembelian

Sumber: Data Olahan, 2020

Berdasarkan hasil dari pengolahan data yang disajikan pada tabel 2 diatas, maka didapat persamaan regresi linier sederhana sebagai berikut :

$$
\begin{aligned}
& \mathrm{Y}=\mathrm{a}+\mathrm{bX} \text {, dimana } \\
& \mathrm{Y}=12.266+0.655 \mathrm{X} \\
& \text { Persamaan regresi diatas dapat }
\end{aligned}
$$
dijelaskan sebagai berikut :

1. Nilai konstanta (a) $=12.266$ ini menyatakan bahwa variabel promosi penjualan $(\mathrm{X})$, dianggap konstan maka variabel keputusan membeli (Y) adalah sebesar 0. 655 .
2. Koefisien regresi variabel promosi penjualan $(\mathrm{X})=0.655$ ini berarti jika terjadi perubahan pada $\mathrm{X}$ (promosi penjualan) sebesar satu satuan, maka nilai Y (keputusan membeli) akan naik sebesar 0.655

\section{Uji t}

Berdasarkan hasil uji $\mathrm{T}$, diperoleh nilai thitung sebesar 7.005 lebih besar dari t tabel dengan nilai ttabel sebesar 2.009, dengan tingkat signifikansi sebesar $0.000<$ 0.05. Dengan demikian berarti variabel promosi penjualan $(\mathrm{X})$ berpengaruh signifikan terhadap variabel keputusan pembelian (Y). Sehingga dapat disimpulkan bahwa promosi penjualan berpengaruh signifikan terhadap keputusan pembelian mebel pada CV. Lautan Rezeki Pekanbaru.

\section{Koefisien Determinasi $\left(\mathbf{R}^{\mathbf{2}}\right)$}

Nilai Adjusted $R$ Square digunakan untuk mengetahui besarnya persentase sumbangan atau kontribusi variabel bebas promosi penjualan $(\mathrm{X})$, terhadap variabel terikat keputusan membeli (Y). Hasil koefisien determinasi dapat kita lihat pada tabel dibawah ini

\section{Tabel 3 Nilai Koefisien Determinasi} Model Summaryb

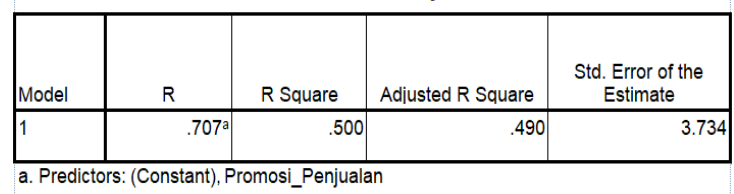

b. Dependent Variable: Keputusan Pembelian

Sumber: Data Olahan, 2020

Dari tabel 3 dapat dilihat bahwa nilai $\mathrm{R}$ Square sebesar 0.500 artinya sumbangan atau kontribusi variabel bebas terhadap variabel terikat sebesar 0.500 atau sebesar 50\%. Maka dalam penelitian ini dapat disimpulkan bahwa variabel promosi penjualan berpengaruh sebesar $50 \%$ terhadap keputusan membeli keputusan membeli mebel pada CV. Lautan Rezeki Pekanbaru. sedangkan sisanya $50 \%$ dipengaruhi oleh variabel lain yang diabaikan atau tidak diteliti dalam penelitian ini. 


\section{SIMPULAN}

Berdasarkan hasil penelitian yang telah dilakukan mengenai pengaruh promosi penjualan terhadap keputusan pembelian mebel pada CV. Lautan Rezeki Pekanbaru, maka berikut ini penulis mengambil kesimpulan yaitu :

1. Berdasarkan hasil uji deskriptif diperoleh hasil bahwa seluruh variabel dalam penelitian dikatakan baik dengan rata-rata 4.03 untuk variabel promosi penjualan. Sedangan untuk variabel keputusan membeli juga dinilai baik dengan rata-rata 3.86. Maka dapat disimpulakn bahwa promosi penjualan yang dilakukan oleh dapat dikatakan baik.

2. Berdasarkan hasil uji $\mathrm{T}$, diperoleh nilai $t_{\text {hitung }}$ sebesar 7.005 lebih besar dari $t$ tabel dengan nilai $t_{\text {tabel }}$ sebesar 2.009, dengan tingkat signifikansi sebesar $0.000<0.05$. Dengan demikian berarti variabel promosi penjualan (X) berpengaruh signifikan terhadap variabel keputusan pembelian (Y). Sehingga dapat disimpulkan bahwa promosi penjualan berpengaruh signifikan terhadap keputusan pembelian mebel pada CV. Lautan Rezeki Pekanbaru.

3. Berdasarkan hasil uji determinasi, Maka dalam penelitian ini dapat disimpulkan bahwa variabel promosi penjualan berpengaruh sebesar $50 \%$ terhadap keputusan membeli keputusan membeli mebel pada CV. Lautan Rezeki Pekanbaru. sedangkan sisanya $50 \%$ dipengaruhi oleh variabel lain yang diabaikan atau tidak diteliti dalam penelitian ini.

\section{DAFTAR RUJUKAN}

Andespa, Roni, 2012. Metodologi Riset Bisnis. Al-Huda Press :PekanbaruRiau

Alma, Buchari. 2004. Manajemen Pemasaran dan Pemasaran Jasa. Cetakan Keenam, Alfabeta, Bandung.
2002. Manajemen

Pemasaran dan Pemasaran Jasa. CV Alvabeta: Bandung

Arikunto, Suharsimi. 2010. Prosedur Penelitian Suatu Pendekatan Praktik. Jakarta : Reneka Cipta.

Basu, Swasta dan Irawan. 2008.Manajemen Pemasaran Modern. Yogyakarta: Liberty

Dharmesta dan Irawan, 2005, Manajemen Pemasaran Modern, Edisi Kedua, Yogyakarta : Liberty

Tjiptono, Fandi, Gregorius Chandra, 2012. Pemasaran Strategik edisi 2. Yogyakarta : CV Andi Offset

Husein, Umar. 2011. Metode Penelitian Untuk Skripsi dan Tesis Bisnis Edisi 11. Jakarta: PT Raja Grafindo Persada Maharyani. 2009. Jurusan Manajemen. Pengaruh Promosi Penjualan Terhadap Keputusan Pembelian Konsumen Cat Merek Jotun Pada CV. Wira Nusa Indonesia Di Pekanbaru.

J. Supranto. 2009. Statistik Teori dan Aplikasi Edisi Ketujuh. Jakarta: Erlangga.

Kotler, Philip 2005. Manajemen Pemasaran, diterjemahkan oleh Benyamin Molan. Edisi kesebelas, Jilid II, PT. Indeks Gramedia, Jakarta. 2005. Manajamen

Pemasaran, Jilid 1 dan 2. Jakarta: PT. Indeks Kelompok Gramedia.

\begin{tabular}{lcc} 
& 2000. & Manajemen \\
\hline Pemasaran. & Edisi & Mileinium. \\
Jakarta : & PT. Indeks & Kelompok \\
Gramedia. & &
\end{tabular}

Kotler, Philip dan Kevin Lane Keller,(2006), Marketing

Management, Pearson Education Inc.

Kotler, Philip \& Gary Armstrong. 2008. Prinsip-Prinsip Pemasaran. Erlangga. Jakarta.

. 2004. Dasar-dasar Pemasaran. Penerbit PT. Indeks Kelompok Gramedia Jakarta.

Kotler, Philip, 2009. Manajemen Pemasaran Jilid 9. Jakarta : PT. Prehallindo 
Noor, Maesa Merdiana, 2008. Pengaruh

Promosi Penjualan Terhadap

Keputusan Pembelian Konsumen Pada

D'loops Clothing Di Bandung.

Fakultas Bisnis dan Manajemen,

Universitas Widyatama. Skripsi.

Nurbiyati, Titik dan Machfoodz, Mahmud, 2005. Manajemen Pemasaran.

Kontmporer. Cetakan 1. Kayon.

Yogyakarta.

Stanton, J. William, 2006. Manajemen Pemasaran. Teori dan Aplikasi. Linda Karya. Bandung

Sunyoto, Danang, 2013. Perilaku Konsumen, CAPS (Center of Academy Publishing Service), Yogyakarta.

Sugiyono. 2009. Metode Penelitian Bisnis : Pendekatan Kuantitatif, Kualitatif dan R\&D. Bandung : Alfabeta. 